\title{
HUBUNGAN PEMBINAAN KEMAMPUAN MENGAJAR GURU DAN ETOS KERJA GURU SEKOLAH MENENGAH PERTAMA (SMP) NEGERI KABUPATEN TABALONG
}

\author{
H. Abdul Hafiz ${ }^{1 *}$ Jumriadi $^{1}$ \\ Jurusan IPS, Universitas Terbuka \\ Email: *ahafiz@ecampus.ut.ac.id
}

\begin{abstract}
Educational institutions are institutions which responsible for improving human resources and must be supported by educators with a high work ethic to produce quality human resources. Based on these facts, the researchers wanted to know the description of teaching ability development by the headmaster to the teachers and the relationship between teaching ability development from the principal and the work ethic of teachers who were in SMP Negeri Kabupaten Tabalong. Based on the results of the study it was found that the implementation of teaching ability development conducted by the headmaster was in the good category and there was a significant relationship between teaching ability development conducted by the headmaster and the teacher's work ethic.
\end{abstract}

Key Words: Teacher Teaching Ability Development and Teacher's Work Ethic

\begin{abstract}
ABSTRAK
Lembaga pendidikan merupakan lembaga yang bertanggung jawab dalam meningkatkan sumber daya manusia dan harus didukung oleh pendidik (guru) dengan etos kerja yang tinggi agar dapat menghasilkan sumber daya manusia berkualitas. Berdasarkan fakta tersebut, maka peneliti ingin mengetahui gambaran pembinaan kemampuan mengajar oleh kepala sekolah kepada guru-guru dan hubungan antara pembinaan kemampuan mengajar dari kepala sekolah dan etos kerja guru yang berada di SMP Negeri Kabupaten Tabalong. Berdasarkan hasil penelitian diketahui bahwa pelaksanaan pembinaan kemampuan mengajar yang dilakukan oleh kepala sekolah termasuk kategori baik dan ada hubungan yang signifikan antara pembinaan kemampuan mengajar yang dilakukan oleh kepala sekolah dan etos kerja guru.
\end{abstract}

Kata Kunci: Pembinaan Kemampuan Mengajar Guru dan Etos Kerja Guru

\section{PENDAHULUAN}

Peningkatan kualitas sumber daya manusia merupakan kenyataan yang harus dilakukan secara terarah, intensif, efektif, dan efesien dalam proses pembangunan agar bangsa ini tidak kalah bersaing dalam menjalani era globalisasi. Lembaga pendidikan merupakan lembaga yang memiliki tanggung jawab dalam meningkatkan sumber daya manusia yang tentunya harus memiliki tenaga pendidik yang berkualitas, professional dan memiliki etos kerja yang tinggi agar hasil pendidikan yang diharapkan dapat maksimal, karena etos kerja guru sangat berperan penting dalam menentukan keberhasilan pendidikan di sekolah.

Berdasarkan latar belakang di atas, maka penelitian ini bertujuan untuk mengetahui gambaran pembinaan kemampuan mengajar yang dilakukan oleh kepala sekolah kepada guru-guru SMP Negeri di Kabupaten Tabalong hubungan antara pembinaan kemampuan mengajar dari kepala sekolah dan etos kerja guru SMP Negeri di Kabupaten Tabalong.

Guna terarahnya penelitian yang dilaksanakan, maka peneliti melakukan penelusuran terlebih dahulu berkenaan 
dengan kepustakaan yang mendasari pelaksanaan penelitian, diantaranya:

\section{Pembinaan Guru}

Ada beberapa istilah tentang pembinaan guru. Secara terminologis, pembinaan guru sering diartikan sebagai serangkaian usaha bantuan kepada guru, terutama bantuan yang berwujud layanan profesional yang dilakukan oleh kepala sekolah, penilik sekolah dan pengawas serta pembina lainnya untuk meningkatkan proses dan hasil belajar (Imron, 1995: 9). Menurut Pidarta (1992: 4) mengemukakan bahwa, pengertian supervisi meliputi tiga unsur yaitu: unsur proses pengarahan, bantuan atau pertolongan dari pihak atasan atau pihak yang lebih memahami, unsur guru-guru dan personalia sekolah lainnya yang berhubungan langsung dengan belajar para siswa sebagai pihak yang diberi pertolongan, unsur proses belajar mengajar sebagai obyek yang diperbaiki.

$$
\text { Pada hakekatnya pengertian }
$$

pembinaan guru/supervisi adalah serangkaian bantuan yang berwujud layanan profesional yang diberikan oleh orang yang lebih ahli (kepala sekolah, pengawas, ahli lainnya) kepada guru dengan maksud agar dapat meningkatkan kualitas proses dan hasil belajar sehingga tujuan pendidikan yang direncanakan dapat tercapai.

\section{Pembinaan Kemampuan Mengajar oleh Kepala Sekolah}

a. Pembinaan dibutuhkan di sekolah menengah
Sardjonopriyo
(1992: 3-4)
mengatakan bahwa, supervisi dibutuhkan di sekolah menengah karena :
1) Adanya pertumbuhan yang pesat dari sekolah-sekolah menengah dan meningkatnya jumlah murid- muridnya sehingga menyebabkan timbulnya masalah-masalah pengajaran, yang mana membutuhkan adanya program supervisi yang baik.

2) Guru-guru sekolah menengah hanya terbatas dari lulusan sekolah pendidikan guru yang secara terbatas dipersiapkan dalam hal mengajar. Oleh karena itu bagi mereka dibutuhkan pembinaan yang baik.

3) Adanya perubahan metodemetode mengajar yang lebih menekankan perbedaanperbedaan individual, hal ini menuntut adanya pembinaan bagi guru yang pada umumnya kurang pengalaman dalam menggunakan metode-metode yang baru.

Salah satu tugas dari kepala sekolah di suatu lembaga pendidikan sekolah menengah adalah sebagai supervisor yang harus bertanggung jawab pada penyelenggaraan kegiatan belajar mengajar dan meningkatkan hasilnya.

\section{b. Kemampuan mengajar}

Kemampuan mengajar adalah kemampuan esensial yang harus dimiliki oleh guru menutut Imron (1995: 169) antara lain : kemampuan merencanakan pengajaran, kemampuan melaksanakan prosedur pengajaran, kemampuan melaksanakan hubungan pribadi dengan siswa.

\section{c. Pembinaan kemampuan mengajar} Pidarta (1992: 209) metode yang dipakai dalam melaksanakan supervisi dinamakan teknik supervisi yang dapat berupa teknik individual bila melaksanakan supervisi terhadap perseorangan dan teknik kelompok bila melakukan supervisi terhadap kelompok guru.

Berdasarkan uraian beberapa teknik supervisi dari berbagai sumber maka dapat dipahami bahwa, berbagai teknik supervisi dapat dimanfaatkan bagi para pembina guru dalam 
melaksanakan pembinaan kemampuan mengajar sehingga dapat menentukan teknik supervisi yang dipergunakan adalah sesuai dengan kebutuhan atau tujuan yang akan disupervisi. Sebab tidak ada teknik supervisi yang paling baik.

\section{Etos Kerja}

\section{a. Pengertian etos kerja}

Magnis (dalam Zahera, 1998: 118) menyatakan bahwa, etos berarti sikap, kehendak yang dituntut terhadap kegiatan tertentu, dan etos kerja adalah sikap dasar seseorang atau kelompok orang dalam melakukan pekerjaan.

Dari beberapa pengertian etos kerja diatas maka dapat dipahami bahwa etos kerja adalah sikap, kehendak atau kebiasaan seseorang atau kelompok yang bersifat etis dalam melaksanakan pekerjaan.

\section{b. Etos kerja guru}

Membahas etos kerja guru sama halnya dengan mempertanyakan semangat kerja yang ditunjukan guru dalam menggeluti profesinya, baik dalam kelas maupun kehidupan masyarakat. Zahera (1998: 119) menyatakan bahwa, etos kerja guru adalah etos kerja dalam profesi guru yang dilihat dari tanggung jawab, disiplin, dan upaya keras guru-guru dalam menjalankan tugasnya.

Indikator etos kerja guru meliputi: 1) Dedikasi (disiplin, tepat waktu, tanggung jawab, loyalitas, etikat baik, semangat, kesungguhan, komitmen yang positiv, kegairahan dalam bekerja dan memiliki akuntabilitas). 2) Unjuk kerja kemampuan mengajar ( unjuk kerja dalam kegiatan belajar mengajar dan kreativitasnya). 3) Kemampuan melaksanakan evaluasi (menilai prestasi/ menguji). 4) Kemampuan pemecahan masalah (pengakuan kelemahan diri sendiri, penghargaan terhadap kemampuan orang lain dan toleransi). 5) Kemampuan penguasaan bahan (penguasaan materi pelajaran dan mengembangkan materi). 6) Partispasi (sosial, bekerja sama, rapat, pertemuan ilmiah). 7) Kemampuan mengadakan penelitian.

\section{c. Hubungan pembinaan kemampuan mengajar dengan etos kerja guru}

Kepala sekolah sebagai supervisor memiliki kompetensi yang menurut Neagley (dalam Pidarta, 1992: 57) meliputi kegiatan: mengembangkan kurikulum, mengorganisasi pengajaran, menyiapkan staf pengajar, menyiapkan fasilitas belajar, menyiapkan bahan-bahan pelajaran, menyelenggarakan penataran guru, membina anggota staf pengajar, mengkordinasi layanan terhadap siswa, mengembangkan hubungan dengan masyarakat, menilai pengajaran.

Jasrial (dalam Pidarta, 1999: 278) mengemukakan bahwa, ada hubungan yang berarti antara keteladanan atasan langsung dan moral kerja. Selanjutnya Lovell and Wiles (1983: 33) mengemukakan bahwa, "Supervisors worked at develoving a convortable and facilitating climate".

Pidarta (1999: 287) mengemukakan bahwa, pembentukan etos kerja dosen dapat terlaksanan jika para guru besar dan para manajer Perguruan Tinggi menjadi contoh pemilikan etos kerja dan mereka harus memberi pembinaan kepada para dosen agar etos kerja dosen dapat meningkat. Kemudian Moedjiarto (1997: 16) mengemukakan bahwa, secara 
umum kepala sekolah yang efektif memfokuskan tindakan-tindakannya pada penetapan tujuan sekolah, mendefenisikan tujuan sekolah, memberikan sumber-sumber yang diperlukan untuk terjadinya belajar. Selain itu tindakan kepala sekolah juga untuk mensupervisi, mengevaluasi guru, mengkoordinasi program-program pengembangan staf, dan menciptakan hubungan kesejawatan dengan dan antar guru.

Berdasarkan uraian tentang kompetensi yang dimiliki oleh supervisor dan hubungan pembinaan dari kepala sekolah dengan etos kerja guru maka dapat dipahami bahwa ada hubungan yang positif antara pembinaan kemampuan mengajar dari kepala sekolah dengan etos kerja guru. Hal ini sangat dimungkinkan karena kepala sekolah bertanggung jawab atas keberhasilan pendidikan disekolahnya agar gurunya memiliki etos kerja yang baik.

\section{METODE PENELITIAN}

Penelitian ini adalah penelitian deskriptif korelasi, dengan variabel bebas yaitu pembinaan dan kemampuan mengajar, sedangkan variabel terikatnya berupa etos kerja.

Populasi dalam penelitian ini adalah seluruh kepala sekolah dan guru SMP Negeri Tabalong dengan jumlah 28 kepala sekolah dan guru 329 orang. Pengambilan sampel untuk penelitian dilakukan dengan teknik cluster proposional random purposive sampling. Dua puluh delaan SMP Negeri Tabalong telah terbagi menjadi 4 kelompok wilayah Kancab, yaitu Kancab Kelua, Kancab Muara Iya, Kancab Haruai dan Kancab Tanjung. Banyaknya SMP Negeri yang menjadi sampel adalah 5 SMP Negeri yang diambil dari 4 (empat) wilayah secara propesional random.

Selanjutnya dari setiap sekolah yang terpilih sebagai sampel diambil maksimal 10 guru laki-laki dan 10 guru perempuan karena jumlah mata pelajaran di SMP ada 10 macam (pendidikan Agama, PPKN, Bahasa Indonesia, Bahasa Inggeris, Matematika, IPS,IPA, Penjaskes, KTK, Mulok). Penetapan sampel secara ringkas dapat dilihat pada Tabel 1 berikut.

\section{Tabel 1. Sampel Penelitian}

\begin{tabular}{clccc}
\hline No & \multicolumn{1}{c}{ SMP Negeri } & L & P & Jlh \\
\hline 1. & 1. Kelua & 8 & 10 & 18 \\
\hline 2. & 1. Muara Uya & 5 & 7 & 12 \\
\hline 3. & 1. Haruai & 10 & 9 & 19 \\
\hline 4. & 1. Tanjung & 10 & 10 & 20 \\
\hline 5. & 2. Tanjung & 10 & 10 & 20 \\
\hline & Jumlah & 43 & 46 & 89 \\
\hline
\end{tabular}

Keterangan:

L: Laki-laki

P: Perempuan

Teknik pengumpulan data penelitian ini meliputi 3 bagian, yaitu (1) identifikasi variabel, (2) pengembangan instrumen penelitian dan pengukuran, dimana instrumen penelitian yang digunakan berupa angket. Bentuk angket yang digunakan adalah jenis angket tertutup yaitu yang berisi pernyataan yang disertai dengan pilihan jawaban, responden memilih jawaban yang sesuai dengan keadaan sebenarnya. (3) Teknik pengumpulan data, dimana teknik yang digunakan untuk mengumpulkan data tentang pembinaan kemampuan mengajar dan etos kerja guru di Kabupaten Tabalong berupa angket Untuk memudahkan pengolahan data dari angket tersebut dilakukan penskoran. Penskoran yang dilakukan didasarkan pada bentuk Skala Likert. Sugiono (1992: 67) mengatakan bahwa skala Likert digunakan untuk mengukur sikap, pendapat, dan persepsi seseorang atau sekelompok orang tentang fenomena sosial. Jawaban setiap item instrumen yang menggunakan Skala Likert mempunyai gradasi dari sangat positif sampai dengan sangat negatif. Selain dengan angket data juga dikumpulkan melalui wawancara dengan kepala sekolah.

Data-data penelitian yang telah diperoleh selanjutnya dianalisis, yang meliputi (1) pendeskripsian hasil penelitian (2) pengujian persyaratan analisis dengan uji normalitas dan homogenitas, (3) pengujian hipotesis penelitian 
menggunakan uji t untuk menguji ada atau tidaknya perbedaan etos kerja guru lakilaki dan guru perempuan, (4) pengujian untuk mengetahui ada atau tidaknya hubungan antara pembinaan kemampuan mengajar dan etos kerja guru menggunakan korelasi sederhana.

\section{HASIL DAN PEMBAHASAN}

Berdasarkan hasil pengolahan data penelitian yang dilakukan, selanjutnya dideskripsikan, diuji persyaratan analisis dan analisis hipotesis, maka dapat diuraikan sebagai berikut:

\section{Pembinaan Kemampuan Mengajar}

Deskripsi pembinaan kemampuan mengajar secara teoritik berada pada kisaran skor antara 10 sampai dengan 40 sedangkan skor pembinaan kemampuan mengajar yang diperoleh berada dalam rentang antara 20 dan 39. Berdasarkan perhitungan frekuansi kelompok skor yang dilakukan dengan program SPSS, diketahui bahwa sebagian besar guru memiliki skor pada kelompok >30 $(70,77 \%)$ dan sebagian kecil guru memiliki skor pada kelompok 20 s.d. $\leq$ $30(29,23 \%)$. Data dapat dilihat pada pada Tabel 2.

Tabel 2. Kelompok Skor Pembinaan Kemampuan Mengajar

\begin{tabular}{cccc}
\hline Interval & $\mathbf{f}$ & $\mathbf{( \% )}$ & Klasifikasi \\
\hline$>30$ & 63 & 70,77 & Baik \\
20 s.d. $\leq 30$ & 26 & 29,23 & Sedang \\
$<20$ & 0 & 0 & Jelek \\
\hline Jumlah & 89 & $100 \%$ & \\
\hline
\end{tabular}

Sumber : Hasil penelitian, 2017

Hal tersebut menunjukkan pembinaan kemampuan mengajar yang dilakukan oleh kepala sekolah yang dirasakan para guru berada pada klasifikasi yang baik.

Sebaran skor dari data pembinaan kemampuan mengajar yang dilakukan oleh kepala sekolah juga dilanjutkan dengan pengujian normalitas sebaran menggunakan program SPSS. Berdasarkan hasil pengujian diketahui bahwa persyaratan analisis normalitas (pengujian normalitas) terpenuhi untuk pembinaan kemampuan mengajar yang dilakukan oleh kepala sekolah. Selain itu, pada pengujian homogenitas data pembinaan kemampuan mengajar juga dipereloh hasil bahwa persyaratan analisis homogenitas telah terpenuhi atau dengan kata lain telah terjadi homogenitas pada variabel pembinaan kemampuan mengajar dengan dasar variabel etos kerja guru.

Berdasarkan analisis data tentang pembinaan kemampuan mengajar yang dilakukan oleh kepala sekolah, diperoleh gambaran bahwa pelaksanaan pembinaan kemampuan mengajar di SMP Negeri Tabalong termasuk kategori baik. Kenyataan tersebut menunjukan bahwa kepala sekolah telah melaksanakan salah satu tugas dari kepala sekolah sebagai supervisor di sekolahnya. Hal-hal yang mendukung hasil penelitian tersebut antara lain :

1. Menurut Pidarta (1992: 80) bahwa, kepala sekolah sebagai supervisor yang bertugas mengatur seluruh aspek kurikulum yang berlaku disekolah itu meliputi : materi pelajaran, proses belajar mengajar, evaluasi kurikulum, pengembangan kurikulum.

2. Hal ini sejalan dengan pelaksanaan penelitian kinerja kepala sekolah SMP dan SMA menurut laporan Dinas Dikbud pada tahun 2000 yaitu terdapat komponen kepala sekolah sebagai supervisor yang harus dilaksanakan antara lain :

a. Menyusun program supervisi pendidikan (program supervisi kegiatan belajar mengajar, BK, laboratorium, perpustakaan, ulangan umum, Ebta/Ebtanas dan progam kegiatan ekstra kurikuler).

b. Melaksanakan program supervisi pendidikan (program supervisi klinis dan non klinis, program supervisi ekstera kurikuler). 
c. Memanfaatkan hasil supervisi untuk meningkatkan kinerja guru.

\section{Etos Kerja Guru}

Deskripsi etos kerja guru secara teoritik berada pada kisaran skor antara 30 sampai dengan 120 sedangkan skor etos kerja guru yang diperoleh berada dalam rentang antara 77 dan 115. Berdasarkan perhitungan frekuensi kelompok skor yang dilakukan dengan program SPSS, diketahui bahwa sebagian sangat besar guru memiliki skor pada kelompok $>90$ (85,39\%); dan sebagian sangat kecil guru memiliki skor pada kelompok 60 s.d. $\leq 90(14,61 \%)$. Data dapat dilihat pada Tabel 3.

Tabel 3. Kelompok Skor Etos Kerja Guru

\begin{tabular}{cccc}
\hline Interval & $\mathrm{f}$ & $(\%)$ & Klasifikasi \\
\hline$>90$ & 76 & 85,39 & Tinggi \\
60 s.d. $\leq 90$ & 13 & 14,61 & Sedang \\
$<60$ & 0 & 0 & Rendah \\
\hline Jumlah & 89 & $100 \%$ & \\
\hline
\end{tabular}

Sumber : Hasil penelitian, 2017

Hal tersebut menunjukkan etos kerja guru berada pada klasifikasi yang tinggi.

Sebaran skor dari data etos kerja guru juga dilanjutkan dengan pengujian normalitas sebaran menggunakan program SPSS. Berdasarkan hasil pengujian diketahui bahwa persyaratan analisis normalitas (pengujian normalitas) terpenuhi untuk etos kerja guru.

Berdasarkan hasil analisis, diperoleh gambaran bahwa etos kerja guru SMP Negeri di Kabupaten Tabalong termasuk kategori tinggi. Kenyataan tersebut menunjukkan bahwa rata-rata guru pada SMP Negeri di Kabupaten Tabalong telah melaksanakan tugas dengan baik.

Hal-hal yang mendukung hasil penelitian ini antara lain :

1. Adanya kompetensi guru yang harus dimiliki menurut Pidarta
(1999: 283), yaitu: a). Menguasai landasan pendidikan.; b). Mengenal fungsi dan program layanan bimbingan penyukuhan di sekolah; c). Mengenal dan menyelenggarakan administrasi sekolah; d). Memahami prinsipprinsip dan menafsirkan hasil penelitian pendidikan guna kepentingan pengajaran; e). Mengelola program belajar mengajar; f). Mengelola kelas; g). Mengelola media; h). Mengelola interaksi belajar mengajar; i). Menilai prestasi siswa untuk kepentingan pengajaran; j). Menguasai bahan. Kompetensikompetensi diatas sebagian berhubungan langsung dengan aktifitas guru dalam proses belajar mengajar telah dilaksanakan dengan baik.

2. Unsur-unsur kemampuan guru menurut Imron (1995: 169) yaitu kemampuan merencanakan pengajaran, kemampuan melaksanakan prosedur pengajaran dan kemampuan melaksanakan hubungan pribadi dengan siswa telah dilaksanakan oleh guru dengan baik.

3. Kenyataan tersebut menunjukan bahwa, rata-rata guru pada SMP Negeri di Kabupaten Tabalong telah melaksanakan tugasnya sejalan dengan indikator etos kerja dalam dunia pendidikan yang pernah dirumuskan melalui konsultasi para ahli dalam laporan Barto dkk. (1997: 20 - 21) meliputi : dedikasi, unjuk kerja kemampuan mengajar, kemampuan melaksanakan evaluasi, kemampuan memecahkan masalah, kemampuan penguasaan bahan, partisipasi, kemampuan mengadakan penelitian. 


\section{a. Etos Kerja Guru Laki-Laki}

Deskripsi etos kerja laki-laki guru secara teoritik berada pada kisaran skor antara 30 sampai dengan 120 sedangkan skor etos kerja guru laki-laki yang diperoleh berada dalam rentang antara 77 dan 113. Berdasarkan perhitungan frekuensi kelompok skor yang dilakukan dengan program SPSS, diketahui bahwa sebagian sangat besar guru memiliki skor pada kelompok $>90$ $(86,05 \%)$; dan sebagian sangat kecil guru memiliki skor pada kelompok 60 s.d. $\leq 90(13,95 \%)$. Data dapat dilihat pada Tabel 4.

Hal tersebut menunjukkan etos kerja guru laki-laki berada pada klasifikasi yang tinggi.

Tabel 4. Kelompok Skor Etos Kerja Guru Laki-Laki

\begin{tabular}{cccc}
\hline Interval & $\mathbf{f}$ & $\mathbf{( \% )}$ & Klasifikasi \\
\hline$>90$ & 37 & 86,05 & Tinggi \\
60 s.d. $\leq 90$ & 6 & 13,95 & Sedang \\
$<60$ & 0 & 0 & Rendah \\
\hline Jumlah & 43 & $100 \%$ & \\
\hline
\end{tabular}

Sumber : Hasil penelitian, 2017

\section{b. Etos Kerja Guru Perempuan}

Deskripsi etos kerja guru perempuan secara teoritik berada pada kisaran skor antara 30 sampai dengan 120 sedangkan skor etos kerja guru perempuan yang diperoleh berada dalam rentang antara 79 dan 115. Berdasarkan perhitungan frekuensi kelompok skor yang dilakukan dengan program SPSS, diketahui bahwa sebagian sangat besar guru memiliki skor pada kelompok $>90$ $(84,78 \%)$; dan sebagian sangat kecil guru memiliki skor pada kelompok 60 s.d. $\leq 90(15,22 \%)$. Data dapat dilihat pada Tabel 5.

Tabel 5. Kelompok Skor Etos Kerja Guru Perempuan

\begin{tabular}{cccc}
\hline Interval & $\mathbf{f}$ & $\mathbf{( \% )}$ & Klasifikasi \\
\hline$>90$ & 76 & 84,78 & Tinggi \\
60 s.d. $\leq 90$ & 13 & 15,22 & Sedang \\
$<60$ & 0 & 0 & Rendah \\
\hline Jumlah & 89 & $100 \%$ & \\
\hline
\end{tabular}

Sumber : Hasil penelitian, 2017
Hal tersebut menunjukkan etos kerja guru perempuan berada pada klasifikasi yang tinggi.

Data mengenai etos kerja guru, baik guru laki-laki maupun guru perempuan dilanjutkan ke tahap pengujian hipotesis.

1. Ditinjau dari ada atau tidaknya perbedaan etos kerja guru lakilaki dan etos kerja guru perempuan

Berdasarkan hasil analisis dengan menggunakan statistik uji perbedaan dua mean untuk mengetahui apakah ada perbedaan yang berarti antara etos kerja guru laki-laki dengan guru perempuan diperoleh simpulan bahwa tidak ada perbedaan antara etos kerja guru laki-laki dengan guru perempuan SMP Negeri Kabupaten Tabalong pada taraf signifikan $5 \%$.

Hal ini menunjukan bahwa guru laki-laki maupun guru perempuan SMP Negeri di Kabupaten Tabalong rata-rata memiliki etos kerja yang sama dalam melaksanakan tugasnya sebagai guru berdasarkan kompetensi yang dimilikinya. Hal-hal yang mendukung hasil penelitian ini adalah :

1. Guru laki-laki maupun perempuan di setiap sekolah mendapatkan pembinaan yang sama dari kepala sekolahnya baik melalui rapat dinas maupun rapat insidental, sehingga etos kerja guru lakilaki maupun perempuan tidak ada perbedaan yang berarti.

2. Laporan penelitian Zahera (1998: 119) menyatakan bahwa, etos kerja guru adalah etos kerja dalam profesi guru yang dilihat dari tanggung jawab, disiplin dan upaya keras guru-guru

dalam 
melaksanakan tugas utamanya yaitu mengajar.

3. Laporan penelitian Barto dkk. (1997: 67) berdasarkan hasil uji hipotesis diperoleh simpulan bahwa, tidak ada perbedaan yang signifikan antara etos kerja dosen FKIP Banjarmasin lulusan S-1 kependidikan dan non kependidikan laki-laki maupun perempuan. Hasil laporan tersebut dapat dianalogkan pada hasil penelitian ini.

2. Ditinjau dari ada atau tidaknya hubungan antara pembinaan kemampuan mengajar dan etos kerja guru

Berdasarkan hasil analisis terdapat hubungan yang signifikan antara pembinaan kemampuan mengajar dan etos kerja guru dengan menggunakan analisis korelasi sederhana dapat diperoleh simpulan bahwa, ada hubungan signifikan antara pembinaan kemampuan mengajar yang dilakukan oleh kepala sekolah dan etos kerja guru SMP Negeri Kabupaten Tabalong.

Kenyataan tersebut menunjukkan bahwa terbentuknya etos kerja guru dapat dipengaruhi oleh pembinaan dari kepala sekolah. Hal ini sejalan dengan Neagley (dalam Pidarta, 1992: 57) yang menyatakan bahwa, kepala sekolah sebagai supervisor memiliki kompetensi yang meliputi; mengembangkan kurikulum, mengorganisasi pengajaran, menyiapkan staf pengajar, menyiapkan fasilitas belajar, menyiapkan bahan-bahan pelajaran, mengkoordinasi layanan terhadap siswa, mengembangkan hubungan dengan masyarakat dan menilai pengajaran. Selain itu, hasil dari penelitian ini juga sejalan dengan hasil penelitian yang dilakukan oleh Riduan (2017: 50) bahwa supervisi yang dilakukan terhadap guru yaitu supervisi akademik dapat meningkatkan kemampuan guru, dalam hal ini adalah guru Pendidikan Agama Islam dalam menggunakan media pembelajaran yaitu LCD.

Pendapat lain yang mendukung adalah dari Yoedoprawiro (dalam Zahera, 1998: 117) menyatakan bahwa mutu pendidikan disuatu lembaga pendidikan dan jenjang pendidikan sangat tergantung pada pimpinan sekolahnya. Oleh karena itu produktivitas guru akan meningkat jika guru-guru mendapatkan pembinaan yang baik dari kepala sekolahnya.

\section{Temuan-Temuan dalam Wawancara dengan Kepala Sekolah}

Adapun hasil wawancara dengan kepala sekolah adalah sebagai berikut:

a. Semua kepala sekolah memiliki program pembinaan kemampuan mengajar yang meliputi: penyusunan program mengajar, kunjungan kelas, pembinaan evaluasi, Ebta Ebtanas dan ekstra kurikuler. Program tersebut merupakan program yang harus ada, karena sekolah merupakan lembaga pendidikan formal yang secara administratif programnya harus dituangkan secara rinci sehingga mudah untuk mengontrol tingkat keberhasilannya.

b. Hal-hal yang khusus ditentukan dalam melaksanakan pembinaan antara lain ada yang mengadakan :

1. Rapat kerja setiap tahun pelajaran baru dengan mendatangkan nara sumber

2. Kegiatan pembinaan kemampuan mengajar melalui Quantum Teaching SMP Negeri di Kabupaten Tabalong. Kegiatan tersebut sejalan dengan upaya 
untuk meningkatkan etos kerja guru sesuai dengan profesinya.

c. Untuk meningkatkan kemampuan dan pengembangan guru, semua kepala sekolah memberikan kesempatan untuk mengikuti penataran, seminar, pelatihan. Upaya ini diharapkan untuk meningkatkan etos kerja guru.

d. Untuk meningkatkan prestasi di bidang akademik bagi siswa SMP Negeri di Kabupaten Tabalong ada yang memberikan tambahan pelajaran pada siang hari atau bimbingan belajar yang sifatnya tidak memaksa kepada siswa, tetapi sekolah menawarkan program bimbingan belajar tersebut kepada orang tua siswa. Hasil yang diperoleh dari bimbingan belajar meningkatkan NEM siswa SMP Negeri di Kabupaten Tabalong.

\section{PENUTUP}

Berdasarkan hasil penelitian dan pembahasan maka dapat disimpulkan sebagai berikut :

1. Pelaksanaan pembinaan kemampuan mengajar yang dilakukan oleh kepala SMP Negeri di Kabupaten Tabalong termasuk kategori baik.

2. a. Etos kerja guru-guru SMP Negeri Kabupaten Tabalong termasuk kategori tinggi

b. Etos kerja guru laki-laki SMP Negeri Kabupaten Tabalong termasuk kategori tinggi

c. Etos kerja guru perempuan SMP Negeri Kabupaten Tabalong termasuk kategori tinggi

3. Tidak ada perbedaan signifikan antara etos kerja guru laki-laki dengan guru perempuan SMP Negeri Kabupaten Tabalong.

4. Ada hubungan yang signifikan antara pembinaan kemampuan mengajar yang dilakukan oleh kepala sekolah dan etos kerja guru di SMP Negeri Kabupaten Tabalong.
Adapun saran yang dapat peneliti sampaikan terkait penelitian yang telah dilaksanakan, diantaranya:

1. Walaupun pembinaan kemampuan mengajar sudah baik, tidak ada salahnya lebih ditingkatkan lagi pelaksanaan pembinaan kemampuan mengajar dari kepala sekolah agar etos kerja guru di SMP Negeri Kabupaten Tabalong.

2. Etos kerja guru di SMP Negeri Kabupaten Tabalong sudah tergolong tinggi, hal ini harus tetap dipertahankan agar pelaksanaan pendidikan di sekolah berjalan dengan baik.

3. Berdasarkan temuan ada sekolah tertentu yang mengadakan variasi dalam pembinaan kemampuan mengajar, misalnya memberikan tambahan pelajaran pada siang hari atau bimbingan belajar yang sifatnya tidak memaksa kepada siswa. Oleh karena itu hendaknya pelaksanaan pembinaan yang dilakukan oleh kepala sekolah di SMP Negeri Kabupaten Tabalong lebih bervariasi agar tidak terjadi kejenuhan dalam melakukan kegiatan mengajar.

4. Kepada pihak yang ingin meneliti lagi dalam bidang ini disarankan untuk mengembangkan kajian dalam hal kinerja guru, prestasi kerja maupun mutu lulusan dari siswa.

\section{DAFTAR PUSTAKA}

Barto, d. (1997). Kaitan antara Indeks Prestasi dengan Etos Kerja Dosen IKIP Surabaya Lulusan S-1. Laporan Penelitian Diseminarkan di Lembaga Penelitian IKIP Surabaya, Surabaya.

Imron, A. (1995). Pembinaan Guru Indonesia. Jakarta: Dunia Pustaka Jaya.

Lovell, J. T., \& Wiles, K. (1983). Supervision for Better Schools. United States of America: Prentice Hall, Incm Englewood Cliffs, N.J.

Moedjiarto. (1997). Peranan Kepala Sekolah dan Guru dalam Meningkatkan Prestasi Belajar SIswa. Laporan Penelitian 
Diseminarkan di Lembaga

Penelitian IKIP Negeri Surabaya,

Surabaya.

Pidarta, M. (1992). Pemikiran Tentang Supervisi Pendidikan. Jakarta: Bumi Aksara.

Riduan, M. (2017). Uoaya Meningkatkan

Kemampuan Guru Pendidikan

Agama Islam dalam Penggunaan

Media Pembelajaran Melalui

Supervisi Akademik di SMP

Negeri 3 Marabahan. Jurnal PTK \&

Pendidikan, 3(1), 41-50.

Sardjonopriyo, P. (1992). Supervisi Demokratis di Sekolah Menengah . Malang: Dioma.

Sugiyono. (2012). Metode Penelitian Kuantitatif, Kualitatif dan $R \& D$. Bandung: Alfabeta.

Wiles, J., \& Bondi, J. (1986). Supervision A Guide to Practice. United States of America: Bell \& Howell Company.

Zahera, S. (1998). Pembinaan yang DIlakukan Kepala Sekolah dan Etos Kerja Guru Sekolah Dasar. Jurnal Ilmu Pendidikan, 5(2), 118127. 